\title{
O nouă formă de deficit de CPT2 la un pacient de 15 ani
}

\section{Cristian Minulescu ${ }^{1,2}$} \\ ${ }^{1}$ Dr. Cristian Minulescu PFA, MedLife, Bucureşti, România \\ ${ }^{2}$ Société Française pour l'Etude des Maladies Héréditaires du Métabolisme, France
}

\begin{abstract}
REZUMAT
În articolul de față, vom prezenta cazul unui pacient în vârstă de 15 ani diagnosticat în România cu o nouă formă de deficit de CPT2 (carnitin-palmitoil-transferază). Acest diagnostic a fost stabilit prin teste genetice și funcționale. În acest mod, dorim să arătăm o posibila etiologie a cazurilor grave de rabdomioliză și să indicăm un tratament pentru aceste cazuri.

Diagnosticul a fost pus târziu întrucât tabloul clinic nu a fost unul specific, manifestările fiind mult timp ignorate sau interpretate greșit ca tulburări de comportament.

Prin prezentul articol, vrem, de asemenea, să atragem atenția asupra unei noi configurații genice care uneori poate duce la crize extrem de severe, cu implicarea riscului vital.

Cuvinte cheie: rabdomioliză, hiperamoniemie, afectare cardiacă, insuficiență renală acută, hipoglicemie
\end{abstract}

\section{INTRODUCERE}

Metabolismul lipidic intră în categoria metabolismului intermediar, care este responsabil de producerea energiei necesare funcționării organismului. Acesta este format din mai multe părți. Prima parte cuprinde sistemul de descompunere a grăsimilor ingerate până la nivelul de acizi grași cu lanț lung, asigurat de enzimele digestive.

Ulterior, acești acizi sunt preluați de către sistemul de transport al acizilor grași cu lanţ lung prin membrana mitocondrială, sistem realizat de trei enzime (CPT1, CPT2, CACT).

Ultima parte este reprezentată de către betaoxidarea mitocondrială, care este deservită de șase enzime (VLCAD, LCHAD, enzima trifuncţională, MCAD, SCAD, SCHAD). Acestea au rolul de a elimina din lanţul acidului gras câte o moleculă de acetil-CoA (1).

O disfuncție a acestor procese va avea trei efecte. Primul efect este o acumulare a acizilor grași care nu mai pot fi degradați. În funcție de enzima implicată, se pot acumula acizi grași cu lanţ lung, mediu sau scurt (2). Betaoxidarea activează piruvat-carboxilaza și, astfel, activează neoglucogeneza (3). O scădere a funcţionării betaoxidării va afecta funcționarea neoglucogenezei și, astfel, va genera hipoglicemie.
O lipsă a corpilor cetonici va face ca mușchiul cardiac și creierul să nu dispună de substrat energetic alternativ în cazul unei hipoglicemii (4). Acest lucru însă este și util pentru diagnostic, noi putând suspecta o tulburare a metabolismului acizilor grași atunci când avem un pacient cu hipoglicemie non sau hipocetotică.

Există și o betaoxidare peroxizomală care degradează acizii grași cu lanț foarte lung. Aceasta nu trebuie confundată cu cea mitocondrială, tabloul clinic fiind complet diferit (5).

Dintre toate aceste entităţi, cele mai periculoase sunt cele care duc la acumularea acizilor grași cu lanț lung. Aceștia sunt toxici atât pentru musculatura scheletică, cât și pentru cea cardiacă. Acumularea lor duce la o rabdomioliză severă, cu risc de insuficiență renală acută și la stop cardiac prin toxicitate miocardică directă sau prin hiperpotasemia secundară rabdomiolizei. Aceste entităţi cuprind deficitul de CPT1, deficitul de CPT2 și CACT, care împreună formează sistemul de transport al carnitinei prin membrana mitocondrială; deficitul primar de carnitină, iar din cadrul tulburărilor de betaoxidare enumerăm deficitul de LCHAD, VLCAD, enzimă trifuncţională şi MADD. 
Deficitul de CPT2 cuprinde trei forme, cea miopatică, cea neonatală și cea infantilă. Sunt raportate puțin peste 300 de cazuri în toată lumea, dintre acestea $86 \%$ reprezentând cazurile de deficit de CPT2 forma musculară. $8 \%$ sunt cazurile infantile și doar $6 \%$ cazurile neonatale.

Tabloul clinic este dominat de pusee de rabdomioliză de severitate variabilă. Aceasta este însoțită de hipoglicemii de post lung și noncetotice. Frecvent, se asociază acestor semne și o hiperamoniemie, în general ușoară spre moderată, dar care, uneori, poate fi severă.

O complicație redutabilă este afectarea cardiacă, care poate fi de tipul insuficiență cardiacă sau apariția unor tulburări de ritm cu risc letal. De asemenea, secundar rabdomiolizei, se poate instala o insuficiență renală acută, care poate impune inițierea dializei.

\section{PREZENTAREA CAZULUI}

\section{Metodologie}

Diagnosticul a fost suspectat în urma unei crize severe de rabdomioliză. Pentru stabilirea acestuia, s-a folosit tehnica NGS (next generation sequencing) pentru secvențierea genelor implicate în rabdomioliza metabolică. Întrucât rezultatul nu a fost unul sigur, teste functionale și enzimatice au fost necesare pentru a stabili cu certitudine etiologia.

\section{Istoric}

Cazul este cel al unui adolescent de sex masculin care nu a avut probleme deosebite până la vârsta de 7 ani. Începând cu vârsta de 7 ani, mama observă că băiatul are o toleranță mai mică la efort comparativ cu alți copii și un apetit alimentar crescut.

La vârsta de 10 ani, este notat primul episod de rabdomioliză, dar care nu este explorat suplimentar. Nu se identifică și pusee de hipoglicemie.

La vârsta de 13 ani, are un nou episod, însă mult mai sever, pentru care necesită internare. În momentul internării, pacientul prezenta dureri precordiale, febră, tulburări de respirație și dureri musculare. Este internat de urgență.

Investigațiile de rutină au evidenţiat o rabdomioliză severă $(\mathrm{CK}>80.000 \mathrm{U} / 1)$, afectare cardiacă $(\mathrm{CKMB}=1.240 \mathrm{mg} / \mathrm{dl})$, citoliză hepatică, mioglobinurie şi hiperuricemie. Criza se remite sub tratament simptomatic și hidratare, fără să fie afectată funcția renală. La externare, pacientul păstrează, totuși, o ușoară rabdomioliză și o discretă creștere a enzimelor miocardice, dar acestea nu au fost clinic manifeste în acel moment.

Evoluția pe parcursul internării a parametrilor relevanți este prezentată în tabelul 1 .
TABEL 1. Datele paraclinice pe perioada spitalizării

\begin{tabular}{|c|c|c|c|c|}
\hline data & CPK & AST & ALT & K \\
\hline $09 / 04 / 2018$ & 81.154 & 1.990 & 528 & 5,3 \\
\hline $10 / 04 / 2018$ & 72.060 & 1.882 & 5.471 & 3,6 \\
\hline $11 / 04 / 2018$ & 38.070 & 1.471 & 437 & 4,2 \\
\hline $12 / 04 / 2018$ & 12.099 & 665 & 252 & 3,2 \\
\hline $13 / 04 / 2018$ & 7.437 & 609 & 327 & 4,7 \\
\hline $16 / 04 / 2018$ & 832 & 83 & 117 & 6,1 \\
\hline $19 / 04 / 2018$ & 1.548 & 93 & 132 & 4,6 \\
\hline
\end{tabular}

Rabdomioliza se păstrează, însă însoțită de dureri musculare mai mult sau mai puțin intense, motiv pentru care se ridică suspiciunea unei miopatii metabolice, cauzele infecțioase și autoimune fiind excluse.

Peste un an, pacientul face o nouă criză de rabdomioliză însoțită de dureri musculare, dar mai puțin severă. În urma acestei noi crize, se solicită un consult de boli congenitale de metabolism.

În momentul consultului, parametrii erau cei prezentaţi în tabelul 2.

TABEL 2. Valorile paraclinice în momentul consultului de specialitate

\begin{tabular}{|c|c|}
\hline Parametru & Valoarea \\
\hline CPK & 535 \\
\hline CKMB & 33 \\
\hline AST & 37,2 \\
\hline ALT & 40,3 \\
\hline NH3 & 91,6 \\
\hline
\end{tabular}

O terapie de urgență pentru normalizarea nivelului amoniemiei cu benzoat de sodiu a fost inițiată, aceasta ducând la o normalizare a nivelului acesteia. Enzimele musculare CPK și CKMB au scăzut și ele în urma unui regim de viață bazat în special pe evitarea efortului fizic. De asemenea, o terapie profilactică cu Carnil a fost iniţiată.

Asocierea dintre rabdomioliză severă și accentuată de puseele febrile, hiperamoniemie, afectare hepatică și cardiacă ridică suspiciunea unei boli congenitale de metabolism.

\section{Diagnostic diferențial}

Principalele entităţi care dau acest tablou clinic sunt:

- Tulburare în betaoxidarea acizilor grași cu lanț lung

- Tulburare în metabolismul carnitinei

- Deficit de CPT1, CPT2, CACT

- Glicogenozele II, III, IV, V, VII, IX

- Citopatii mitocondriale

\section{Stabilirea diagnosticului de certitudine}

O secvențiere genică prin tehnica NGS a genelor implicate în rabdomioliza metabolică a fost efectuată, rezultatul fiind prezentat în figura 1 . 


\begin{tabular}{|c|c|c|c|}
\hline GENE & VARIANT & ZYGOSITY & VARIANT CLASSIFICATION \\
\hline СРT2 & c.1862T>C (p.lle621Thr) & heterozygous & Uncertain Significance \\
\hline CPT2 & c.604T >A (p.Tyr202Asn) & heterozygous & Uncertain Significance \\
\hline POLG & c. $1402 A>G(p . A s n 468$ Asp $)$ & heterozygous & Uncertain Significance \\
\hline SLC22A5 & c. $1255 \mathrm{C}>\mathrm{C}$ (p.Leu419Val) & heterozygous & Uncertain Significance \\
\hline CAA & c.1726G>A (p.Gly576Ser) & heterozygous & Benign (Pseudodeficiency allele) \\
\hline GAA & c.2065G>A (p.Glu689Lys) & heterozygous & Benign (Pseudodeficiency allele) \\
\hline
\end{tabular}

FIGURA 1. Rezultatul secvențierii genice

O primă mutaţie a fost descoperită, în formă heterozigotă, în gena CPT2 (c.1862T >C).. Această mutație nu este cunoscută până acum, nu exista în bazele de date populaționale și nu a fost citată la persoanele cu deficit de CPT2.

$\mathrm{O}$ a doua mutație în gena CPT2 a fost identificată - și anume c.604T $>$ A, tot în formă heterozigotă.. Nu există însă studii care să indice efectul missense asupra structurii și funcționalitaţii proteinei și, ca și în primul caz, această mutaţie este necunoscută, ea neexistând în bazele de date populaționale și nici nu a fost citată la pacienți cu deficit de CPT2.

Dupa cum se știe, deficitul de CPT2 se manifestă prin rabdomioliză severă, hiperamoniemie și afectare cardiacă, aceasta putând explica tabloul clinic, dar, întrucât efectul patogen al celor două mutații nu a fost dovedit, diagnosticul nu poate fi validat doar pe baza acestui rezultat.

Interesant este faptul că o a treia mutaţie, tot în formă heterozigotă, a fost descoperită în gena SLC22A5 (c.1255C >G). Această genă este asociată cu deficitul primar de carnitină. Mutaţia este una cunoscută, ea existând în bazele de date populaţionale, însă nu a fost citată la pacienți cu deficit primar de carnitină.

Tabloul clinic al deficitului primar de carnitină este acelaşi cu cel al deficitului de CPT2 și se potrivește cu tabloul clinico-biologic al pacientului.
Deficitul de POLG este o cauză cunoscută de citopatie mitocondrială, dar, întrucât tabloul clinic al pacientului nu se suprapune cu cele întâlnite în deficitul de POLG, am considerat că mutația descoperită nu are semnificație.

Întrucât rezultatul genetic nu este unul concludent, au fost necesare teste funcționale și enzimatice.

A fost realizat un profil de carnitine, acesta evidențiind un nivel crescut al carnitinei urinare, cu o valoare mai mare decât cea serică (tabelul 4).

\section{TABEL 3. Profilul carnitinelor}

\begin{tabular}{|l|c|c|}
\hline \multicolumn{1}{|c|}{ Parametrul } & Valoarea & Interval de referință \\
\hline Carnitină liberă urinară & $49,8 \mathrm{mg} / 24 \mathrm{~h}$ & $15,2-41,2$ \\
\hline Carnitină totale serică & $8,52 \mathrm{mg} / \mathrm{l}$ & $4,67-9,37$ \\
\hline Carnitină liberă serică & $6,76 \mathrm{mg} / \mathrm{l}$ & $3,96-8,21$ \\
\hline Raport acilcarnitine & 0,26 & $<0,40$ \\
\hline
\end{tabular}

Totuși, putem remarca faptul că nivelul seric reprezintă $>80 \%$ din nivelul urinar, ceea ce face un deficit primar de carnitină puţin probabil întrucât, în această boală, nivelul seric al carnitinei este foarte mic, $<50 \%$ din nivelul urinar. Așadar, am considerat că trebuie luat în calcul faptul că pacientul are o formă nouă de deficit de CPT2, cu o mutație genică nemaiîntâlnită până acum. Pentru a stabili dacă este vorba despre o formă cis sau trans, am decis secvențierea genei CPT2 prin tehnica NGS a ambilor părinți. Rezultatele sunt prezentate în figura 2A,B.

\begin{tabular}{|c|c|c|c|}
\hline GENE & VARIANT & ZYGOSITY & VARIANT CLASSIFICATION \\
\hline CPT2 & c. $1862 \mathrm{~T}>\mathrm{C}$ (p.lle621Thr) & heterozygous & Uncertain Significance \\
\hline
\end{tabular}

FIGURA 2A. Mama

\begin{tabular}{|c|c|c|c|}
\hline GENE & VARIANT & ZYGOSITY & VARIANT CLASSIFICATION \\
\hline СРT2 & c.604T>A (p.Tyr202Asn) & heterozygous & Uncertain Significance \\
\hline POLG & c. $1402 A>G$ (p.Asn468Asp) & heterozygous & Uncertain Significance \\
\hline
\end{tabular}




\begin{tabular}{l}
\hline Test results \\
\hline Carnitine palmitoyitransferase 2 (CPT2) \\
\hline \\
$\begin{array}{l}\text { Activity } \\
\text { Reduced carnitine palmitoyl-COA transferase 2 (CPT2) activity }\end{array}$ \\
\hline in LYC, sample: 20E0081 \\
\hline Conclusion \\
The activity of carnitine palmitoyl-CoA transferase 2 (CPT2) in lymphocytes of the patient was reduced compared to the reference values. This \\
result confirms that the patient has a deficiency of CPT2.
\end{tabular}

FIGURA 3. Activitatea enzimatică reziduală a carnitin-palmitoil-transferazei

Se observă faptul că fiecare părinte este pozitiv pentru câte o mutație identificată la pacient, iar tatăl are, de asemenea, mutația genei POLG identificată la copil, ceea ce conduce la concluzia că mutațiile genei CPT2 sunt în forma trans, iar pacientul este doar purtător al mutației POLG, aceasta neavând un efect patogen.

Întrucât forma trans este patogenă, probabilitatea ca aceste două mutații să determine un real deficit enzimatic este crescută. Acest efect a fost verificat prin măsurarea activității enzimatice reziduale a enzimei CPT2, rezultatul fiind prezentat în figura 3 .

Se observă astfel un deficit enzimatic clar, ceea ce validează diagnosticul și certifică efectul patogen al acestor două noi mutații.

Criteriile pe baza cărora s-a suspectat diagnosticul au fost, aşadar, asocierea dintre rabdomioliză severă, hiperamoniemie și hipoglicemie noncetotică.

\section{Tratamentul şi evoluția}

Primul gest terapeutic inițiat a fost demararea terapiei cu un epurator de amoniac. Acesta a fost benzoatul de sodiu, în doză de $3 \mathrm{~g}$, de 4 ori pe zi. Alegerea a fost motivată în special din motive financiare, fenilbutiratul de sodiu fiind greu accesibil. Valoarea amoniemiei s-a normalizat foarte repede, nefiind necesară asocierea restricției proteice.

Tratamentul cu Carnil a fost oprit, el neavând utilitate în deficitul de CPT2.

Regimul nutriţional este foarte important în această boală - și el constă în reducerea aportului de grăsimi cu lanț lung, astfel încât acestea să nu depășească $30 \%$ din aportul caloric. Totodată, având în vedere că pacientul are peste $120 \mathrm{~kg}$ la $190 \mathrm{~cm}$, s-a încercat și o reducere a aportului de calorii. Complianța terapeutică nu a fost foarte bună însă, chiar și aşa, valorile enzimelor musculare și hepatice au scăzut considerabil (tabelul 4).
TABEL 4. Dinamica valorilor testelor de laborator sub tratament

\begin{tabular}{|c|c|c|}
\hline Data & CK & CKMB \\
\hline $\mathbf{0 8 / 0 7 / 2 0 1 9}$ & $485(\mathrm{VN}<308)$ & $44(<24)$ \\
\hline $\mathbf{1 3 / 1 2 / 2 0 1 9}$ & $1.399(\mathrm{VN}<308)$ & $59(<24)$ \\
\hline $\mathbf{2 5 / 0 3 / 2 0 2 0}$ & $351(\mathrm{VN}<308)$ & - \\
\hline
\end{tabular}

De asemenea, un accent important s-a pus pe profilaxia bolilor infecțioase prin vaccinare antigripală și evitarea contactelor posibil infectante.

Profilaxia hipoglicemiilor a fost realizată cu ajutorului amidonului de porumb de tip Maizena, administrat după fiecare masă. De la iniţierea acestui tratament, nu s-au înregistrat hipoglicemii.

Un protocol de urgență a fost dat pacientului pentru eventualitatea unei noi crize.

Așadar, cel mai important element din tratamentul acestui pacient este regimul alimentar, care urmarește limitarea aportului de lipide.

\section{DISCUŢII}

Tulburările metabolismului acizilor grași pot fi grupate în mai multe categorii:

tulburările betaoxidării intramitocondriale

- deficitul primar de carnitină (OCTN2)

- tulburările căilor de transport ale carnitinei (CPT1, CPT2 și CACT)

Tulburările de betaoxidare reprezintă principala cauză de rabdomioliză metabolică. Întrucât prognosticul acestor boli este unul bun în situaţia în care diagnosticul se stabilește repede, iar tratamentul este instituit rapid, recunoașterea rapidă a acestor cazuri este extrem de importantă. Totuși, anomaliile în căile accesorii betaoxidării, precum transportul carnitinei prin membrana mitocondrială sau prin epiteliul de la nivelul rinichiului, reprezintă o entitate importantă. Tabloul clinic al acestor boli este identic cu cel din tulburările de betaoxidare, diferențierea doar pe criterii clinice fiind practic imposibilă. 


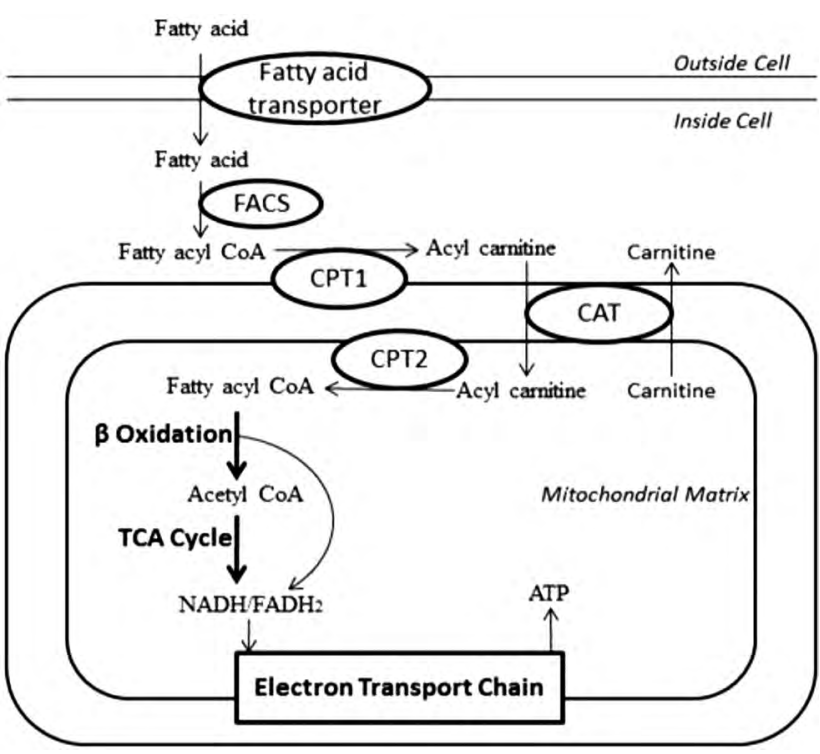

FIGURA 4. Schema betaoxidării acizilor grași și a căilor accesorii (6)

Atât în tulburările betaoxidării, cât și în cele ale căilor conexe se acumulează acizi grași cu lanț lung, care sunt toxici pentru mușchiul scheletic și pentru miocard. Acești acizi nu mai sunt degradați în cadrul procesului de betaoxidare intramitocondrială fie pentru că nu mai pot traversa membrana mitocondrială, aşa cum se întâmplă în tulburările căilor conexe, fie pătrund în mitocondrie, dar enzimele implicate în degradarea lor nu mai funcționează, așa cum se petrece în tulburările de betaoxidare. Rezultatele acestor dereglări sunt o scădere a producției de energie necesară funcționării neoglucogenezei, ceea ce duce la hipoglicemie și o scădere a producției de corpi cetonici, care, în mod normal, ar avea un rol protector pentru creier și cord în timpul unei hipoglicemii. În plus, prin efectul toxic asupra musculaturii striate, se produce o rabdomioliză importantă, care poate duce la insuficiență renală acută sau chiar stop cardiac. De asemenea, în această patologie se observă anomalii de ritm cardiac, care pot fi fatale.

$\mathrm{O}$ altă complicație este reprezentată de inhibarea ciclului ureei, care va produce o hiperamoniemie, care poate fi periculoasă (7).

Epurarea acestor acizi se face cu ajutorul carnitinei, însă în tulburările transportului carnitinei acest tratament nu este util, molecula de carnitină neputând ajunge la nivelul mitocondriei, unde se acumulează acești acizi. O precauție particulară se impune în momentul inițierii tratamentul întrucât, într-o primă fază, prin administrarea de carnitină, nivelul seric al acilcarnitinelor cu lanț lung crește, iar această concentrație crescută poate induce o insuficiență cardiacă farmacorezistentă. Deşi nu există un consens cu privire la modul corect de abordare a acestei probleme, se reco- mandă introducerea prudentă și progresivă a carnitinei și efectuarea zilnică a unui profil de acilcarnitine pentru evaluarea ritmului de creștere a nivelului seric al acestora. În cazul în care nu există această posibilitate, se poate folosi ecografia cardiacă cu studierea fracției de ejecție.

O altă verigă importantă a tratamentului este blocarea catabolismului. În urma catabolismului se produc acizi grași cu lanț lung, iar ritmul de producție depășeşte capacitatea de epurare a carnitinei. Pentru a obține acest lucru, este necesară folosirea unui debit mare de glucoză $(10 \mathrm{mg} / \mathrm{kg} / \mathrm{min})$, însă frecvent este necesară adăugarea unei perfuzii continue cu insulină, speculându-se astfel efectul anabolizant al acestui hormon.

De asemenea, sunt necesare epuratoare de amoniac (benzoat de sodiu, fenilbutirat de sodiu) pentru normalizarea amoniemiei.

Tratamentul de fond se axează pe prevenirea hipoglicemiilor și pe evitarea acumulării acizilor grași cu lanț lung. O atenție deosebită se acordă regimului alimentar, care nu trebuie să conțină grăsimi complexe, aportul acestora trebuind să reprezinte maximum $30 \%$ din aportul caloric. Acesta, combinat cu administrarea de carnitină ca epurator de acilcarnitine, poate realiza un control metabolic bun şi poate preveni crizele.

Hipoglicemiile se pot preveni cu ajutorul amidonului de porumb de tip Maizena.

$\mathrm{O}$ altă modalitate de a realiza acest regim este de a folosi produse speciale. Astfel, conform unei echipe franceze, se pot folosi formule speciale de tipul Monogen care conține $90 \%$ acizi grași cu lanț mediu (AGLM). Pe măsură ce copilul crește și nu mai putem folosi această formulă, se pot folosi alte surse de AGLM precum Liquigen. În acest lapte, se poate adăuga ulei de nucă, care va asigura aportul de acizi grași esenţiali. Restul de calorii va fi asigurat cu ajutorul glucidelor (8).

Deficitul de CPT2 este o tulburare foarte rară, în lume fiind înregistrate până acum aproximativ 350 de cazuri. Sunt înregistrate trei forme: neonatală, hepatomusculocardiacă și miopatică. Acest număr mic de pacienți face ca stabilirea unui protocol terapeutic să fie foarte dificilă.

Majoritatea experților sunt de acord că regimul alimentar este cea mai bună soluție, alături de o gestionare corectă a urgențelor. De asemenea, trebuie evitat postul prelungit. Terapia medicamentoasă nu s-a dovedit eficientă (9). Alte surse sugerează folosirea carnitinei în doză mare $(100 \mathrm{mg} / \mathrm{kg})$ po în timpul puseului acut, dar eficiența este discutabilă (10).

$\mathrm{O}$ atenție deosebită este acordată hidratării în timpul crizei. Această hidratare are rolul de a preveni 
insuficiența renală acută secundară rabdomiolizei. Ea este asociată cu o perfuzie cu glucoză pentru blocarea lipolizei (10).

Conform unui colectiv francez însă, esențială în gestionarea crizei este blocarea lipolizei, hidratarea devenind prioritară doar dacă CK > 20.000 U/1 (11).

Conform unui studiu realizat de un colectiv britanic, principalul organ afectat în timpul acestor faze acute este rinichiul. Terapia promptă, așa cum este descrisă mai sus, a dus însă la recuperarea majorității pacienților și a împiedicat apariția insuficienței multiple de organ (12).

Un alt element important este evitarea anumitor medicamente în timpul crizei, ele putând agrava rabdomioliza. Acestea sunt:

- depakinul

- ibuprofenul

- diazepamul în doze mari

- anestezicele folosite pentru anestezia generală (13).

În ceea ce priveşte tipul de grăsimi folosite în terapia de fond, el este reprezentat de grăsimile cu lanț mediu, care trebuie să asigure $30 \%$ din aportul caloric necesar. Acestea au avantajul că nu necesită prezența carnitinei pentru a pătrunde în mitocondrie și, astfel, nu se vor acumula (8).

Un caz interesant a fost comunicat într-un articol realizat de un colectiv de medici din Croația (14). Aceștia au prezentat cazul unei femei adulte care suferea de această boală. Echipa medicală a folosit ca metodă terapeutică doar un regim bazat pe mese frecvente, fără să fie utilizat un epurator de amoniac sau Maizena. Sub acest tratament, pacienta s-a recuperat complet și rămâne asimptomatică.

$\mathrm{O}$ atenție sporită merită analiza genetică a membrilor familiei acestor pacienți. Într-un studiu realizat de un colectiv de medici din Austria, este descris cazul unei familii în care au fost identificați nu mai puțin de 24 de membri afectați (15). În cazul a doi dintre acești membri, diagnosticul a fost pus postmortem.

Medicii care se confruntă cu pacienți cu rabdomioliză trebuie să știe, de asemenea, că persoanele afectate de un deficit de CPT2 pot fi complet asimptoma-

\section{BIBLIOGRAFIE}

1. Mandal A. Lipid Metabolism - Available at https://www.news-medical. net/life-sciences/Lipid-Metabolism.aspx.

2. Saudubray JM, Van den Berghe G, Walters JH. Disorders of Mitochondrial Fatty Acid Oxidation and Related Metabolic Pathways. In Inborn Metabolic Diseases, $5^{\text {th }}$ edition, Morris M, Spiekerkoetter U (eds.), Berlin-Heidelberg: Springer, 2011, pp. 203-206.

3. de Lonlay P, Dubois S, Valayannopoulos V, Depondt E, Ottolenghi C, Rabier D. Deficit de l'oxydation des acides gras. In Prise en charge médicale et diététique des maladies héréditaires du métabolisme, Paris: Springer, 2013, p. 259.

4. de Lonlay P, Dubois S, Valayannopoulos V, Depondt E, Ottolenghi C, tice și să aibă invetigațiile de laborator normale între puseele de rabdomioliză timp de mai mulți ani, făcând extrem de dificil diagnosticul. Este cazul membrilor unei familii din America de Sud, pentru care, deși aveau pusee de rabdomioliză, diagnosticul a fost stabilit târziu întrucât nu puteau fi evaluați în timpul acestor pusee (16).

O discuție particulară merită forma neonatală. Aceasta este în mod frecvent letală chiar și în prezența unui tratament adecvat. Este esențială recunoașterea rapidă a acesteia și iniţierea unei terapii de blocare a catabolismului cu ajutorul perfuziei cu glucoză cu debit mare ( $>10 \mathrm{mg} / \mathrm{kg} / \mathrm{min})$, ca și al terapiei de epurare a amoniacului. Chiar şi aşa, prognosticul rămâne rezervat, iar decesul apare frecvent (17).

\section{CONCLUZII}

Principala particularitate a acestui caz este reprezentată de faptul că este pentru prima dată când un deficit de CPT2 este datorat acestui binom genic. Corelația fenotip-genotip este greu de realizat și doar o urmărire atentă poate să ofere toate informațiile necesare.

Interesant este însă faptul că pacientul a supraviețuit până la vârsta de 14 ani fără un tratament adecvat și având puține decompensări, doar două fiind cu adevărat grave. Deși în acest moment complianța pacientului nu este foarte bună, el nu a avut noi crize. Toate aceste elemente ne fac să credem că acest binom genic nu este unul care să indice un prognostic prost, dar o concluzie clară nu poate fi trasă în acest moment privind acest lucru.

Utilitatea publicării acestui caz nu este reprezentată doar de faptul ca au fost descoperite două noi mutații, ci mai ales în vederea sensibilizării medicilor pediatri față de această etiologie.

Deficitul de betaoxidare și anomaliile metabolismului carnitinei rămân, totuși, boli cu prognostic bun, de aceea recunoașterea rapidă a manifestărilor acestora este esențială.

Conflict of interest: none declared Financial support: none declared

Rabier D. Déficit de l'oxydation des acides gras. In Prise en charge médicale et diététique des maladies héréditaires du métabolisme, Paris: Springer, 2013, pp. 260-261.

5. Mannaerts GP, Van Veldhoven PP. Peroxisomal Beta-Oxidation [Article in Dutch]. Verh K Acad Geneeskd Belg. 1993;55(1):45-78.

6. Fatty Acid Metabolism - Available at https://step1.medbullets.com/ biochemistry/102031/fatty-acid-metabolism.

7. Saudubray JM, Van den Berghe G, Walters JH. Disorders of Mitochondrial Fatty Acid Oxidation and Related Metabolic Pathways. In Inborn Metabolic Diseases, $5^{\text {th }}$ edition, Morris M, Spiekerkoetter U (eds.), Berlin-Heidelberg: Springer, 2011, p. 207. 
8. de Lonlay P, Dubois S, Valayannopoulos V, Depondt E, Ottolenghi C, Rabier D. Déficit de l'oxydation des acides gras. In: Prise en charge médicale et diététique des maladies héréditaires du métabolisme. Paris: Springer, 2013, p. 264.

9. Bennett M, Stanley C. Carnitine palmitoyl transferase II deficiency myopathic form. Available at https://www.orpha.net/consor/cgi-bin/ OC_Exp.php?Expert=228302.

10. Long chain fat oxidation disorders - standard version, BIMDG protocol, 2017 - Available at http://www.bimdg.org.uk/store/guidelines/ ADULT_FAOD-rev_2015_428281_09012016.pdf.

11. de Lonlay P, Dubois S, Valayannopoulos V, Depondt E, Ottolenghi C, Rabier D. Déficit de l'oxydation des acides gras. In Prise en charge médicale et diététique des maladies héréditaires du métabolisme, Paris: Springer, 2013, p. 263.

12. Ivin N, Della Torre V, Sanders F, Youngman M. Rhabdomyolysis caused by carnitine palmitoyltransferase 2 deficiency: A case report and systematic review of the literature, Journal of Intensive Care Society 2020;21(2):165-173.
13. Wieser T. Carnitine Palmitoyltransferase II Deficiency, GeneReviews $^{\circledR}$ 2019. In: Adam MP, Ardinger HH, Pagon RA, et al., eds.

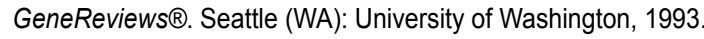

14. Bilić E, Deliu M, Brinar V, Cerimagic D et al. Carnitine palmitoyl transferase type 2 deficiency - Case report and review of the literature. Neurologia Croatica 2013;62:57-62.

15. Zach C, Unterkofler K, Fraunberger P, Drexel H, Muendlein A. Unrecognized High Occurrence of Genetically Confirmed Hereditary Carnitine Palmitoyltransferase II Deficiency in an Austrian Family Points to the Ongoing Underdiagnosis of the Disease. Front Genet. 2019;10:497.

16. Avila-Smirnow D, Boutron A, Beytía-Reyes MLÁ, et al. Carnitine palmitoyltransferase type 2 deficiency: novel mutation in a Native South American family with whole-body muscle magnetic resonance imaging findings: Two case reports. J Med Case Rep. 2018;12(1):249.

17. Malik S, Paldiwal AA, Korday CS, Jadhav SS. Neonatal Carnitine Palmitoyltransferase II Deficiency: A Lethal Entity. J Clin Diagn Res. 2015;9(10):SD01-SD2. 